\title{
INFORMATION AND COMMUNICATION TECHNOLOGY IN MANAGING SMALL AND MEDIUM ENTERPRISES IN NIGERIA
}

\author{
${ }^{* 1}$ Igboeli U. H. and ${ }^{2}$ Bisallah H. I. \\ ${ }^{* 1,2}$ Department of Computer Science, University of Abuja, UNIABUJA, Gwagwalada Abuja \\ "Corresponding Author Email: uchenna.igboeli@uniabuja.edu.ng Phone: +2347068990562
}

\begin{abstract}
Information Communication Technology has generally been acclaimed as an important tool exploited by medium and large-scale enterprises for boosting profitability and enhancing viability. Though Small and Medium Scale Enterprises (SMEs) constitutes a major percentage of businesses in most countries, their ICT adoption rate is still low. This study examined the role of ICT as a tool that SMEs can deploy for the economic development of Nigeria. A questionnaire was employed and administered to a total of 175 SMEs randomly chosen from five different sectors of the Nigeria economy (educational, micro finance, transport, commerce and hospitality). Chi-square test was used to evaluate the hypothesis and the findings of the research revealed that (1) low awareness level of the benefits of ICT incorporation in the management process of most SMEs has been a major cause of its low adoption; (2) poor media transmission framework, high cost of ICT hardware, deficient government support and legislation for internet business among other factors have hindered the adoption of ICT in the management process of SMEs; (3) high cost of funds in Nigeria have also made it unprofitable for SMEs to source fund for ICT expansion and implementation. The research recommends among other measures, the investment on infrastructure and adequate incentives to promote the utilization of ICT among SMEs. Investment banks and other specialized institutions should brace up with their responsibilities and promote local industries through affordable credit schemes.
\end{abstract}

Keywords: adoption, economy, ICT, investment, SME, Nigeria

LICENSE: This work by Open Journals Nigeria is licensed and published under the Creative Commons Attribution License 4.0 International License, which permits unrestricted use, distribution, and reproduction in any medium, provided this article is duly cited.

COPYRIGHT: The Author(s) completely retain the copyright of this published article.

OPEN ACCESS: The Author(s) approves that this article remains permanently online in the open access (OA) mode.

QA: This Article is published in line with "COPE (Committee on Publication Ethics) and PIE (Publication Integrity \& Ethics)". 


\section{INTRODUCTION}

SMEs came into play in the development environment in the late 40s, with the aim being to improve trade and industrialization in the present developed nations. (OECD, 2004). The definitions of SME are usually a function of the country, based on some factors which may include the role they are expected to play in economic development, policies and programmes designed by the agencies or institutions empowered to develop the country's SME. In the Nigeria economy, the National Council of Industry, 2003 categorized enterprises based on three criteria which include: Size, number of employees and total cost including working capital but excluding cost of land acquisition (CBN, 2003). However, in Nigeria, out of all these criteria, the asset base factor is predominantly used. The apex bank in Nigeria (CBN) in its guideline in 2005 on Small and Medium Enterprise Investment Scheme (SMEIS), categorized SMEs as any enterprise with a maximum asset base of 200million naira (about $\$ 420,000$ ) excluding the cost of land acquisition and working capital. Today, various organizations of diverse interests are utilizing ICT all over the world, not only for cutting business costs and improving both management and operational efficiency, but as well as providing robust customer and business relationships. Governments too, are not left out either as they are deploying various ICT platforms to provide better and more efficient services to the people. ICT adoption worldwide requires a business environment that encourages open competition, trust, security, interoperability and standardization and the availability of finance for ICT (UNCTAD 2004). Various governments have recognized the need for ICT adoption by SMEs and have created special groups to study various aspects of ICT adoption in SMEs. This research is an attempt to take a deeper study into the roles ICT can play in the viability of businesses in Nigeria with a view of highlighting some of the salient points which have been neglected or misunderstood by our economic managers. This will go a long way towards making appropriate policies and putting structures in place to enhance the growth and profitability of SMEs.

Every nation needs SMEs because of the significant contribution they make in economic development. These businesses are often classified as the cornerstone and the engine of both the developed and developing economies all over the world as they account for about half of global gross domestic product and 60\%-70\% of employment (Rees, 2019). In most countries, SMEs are also viewed as a major stakeholder in the economy and major source of employment opportunities to the populace. SMEs are often credited as primary agents of innovation, agents of alleviating poverty, economic growth, wealth creation and employment creation. This is primarily because their activities most often involve the business of output expansion, income redistribution, promotion of various levels of indigenous entrepreneurship and production of primary goods. SMEs accounts for almost $70 \%$ of the total the industrial employment in Nigeria and between 10-15\% of the total manufacturing output (Ogbo \& Nwachukwu, 2012). The agricultural sector which comprises mainly of SMEs have promoted indigenous technology and increased utilization of local raw materials. They are the strongest promise we have for industrial growth. In a related study, Abiodun (2014) found that, the performance of SMEs in Nigeria has accounted for over $90 \%$ of Nigerian businesses. This consists of over $95 \%$ of formal manufacturing activities and almost $70 \%$ of industrial businesses. The results from the study show that several policies directed towards SME development have not been able to achieve the desired objectives. The scheme has so many constraints that have been limiting them from deriving maximum benefits from the policies of governments due to administrative bottlenecks and other factors affecting their performance. 
The research aims to examine the role of proper ICT adoption in the management and development of SMEs in Nigeria especially in this $21^{\text {st }}$ century. Businesses are facing all sorts of economic and social challenges and the survival of any enterprise in this age has to adopt some strategic policies and techniques.

\section{BACKGROUND OF LITERATURE}

According to (Techopedia, 2016), "ICT refers to all the technology used to handle telecommunications, broadcast media, intelligent building management systems, audio-visual processing and transmission systems, and networkbased control and monitoring functions".

Though ICT is most often considered an extended synonym for information technology (IT), its scope is broad and robust. ICT has more recently been adopted to describe the embodiment of several technologies and the use of common transmission media and networks to transport various forms of data in diverse formats. Information communication technology has become a major component part of every business irrespective of its size, location and area of operation. ICT drives most business that business owners now find it very difficult to operate during service downtimes. Through adequate deployment of technology, SMEs can benefit enormously by developing capacities for managing their meagre resources, and as a result, enjoy manageable transaction costs and at the same time enjoy rapid flow of information (Minton, 2003). Sajuyigbe \& Alabi (2012) also argue that ICTs can be beneficial in the areas of strategic management, communication and collaboration, customers' access, managerial decision making, data management and knowledge management.

SMEs constitutes essential ingredients in the sustenance and development of the economy. In Nigeria, the case remains the same as they dominate the economy (Mekwunye, 2018), contributing about 76\% of the entire workforce and about 50\% contribution to our GDP and 8\% to exports (BusinessDay, 2019).

Having recognized the role of this sector, the Nigerian government has continued to formulate numerous policies aimed at developing and improving the state of these enterprises. While most of these policies actually failed due to poor implementation, others have recorded a considerable level of success. SMEs constitute a force for the industrial growth and development of the country due to their enormous potentials in the diversification and expansion of industrial production while at the same time contributing to the realization of the basic objectives of economic development (Taiwo et al., 2016). The role of adequate financing to businesses cannot be over emphasized. Business finance is always a major limiting factor and has remained a great challenge especially in respect of SMEs. Yet they require funds from every source available to meet their asset needs, working capital needs, and for expansion. While most of the formal sources may not be easily accessible to most SMEs since majority of them are located and operated by people living in the rural areas (Taiwo et al., 2016), they tend to rely more on the informal sources. These include:
a. Savings
b. Support from family and friends
c. Business partners or associates
d. Lending individuals and groups
e. Co-operative societies 
The utilization of ICT as a tool used for enhancing the role of SMEs in national development has often and always attracted a lot of attention worldwide. While the developed nations have found the need for this and have made ICT an indispensable tool in running successful businesses, most developing and undeveloped economies are still struggling and dragging.

Apulu (2012) acknowledged that as organizations strive to adopt needed ICT applications, other paramount issues relating to power supply, security amongst others, stand as limiting factors to ICT adoption in Nigerian SMEs. Hassan \& Ogundipe (2017) added that competitive pressure, government support, employer's skill are among the salient factors influencing the adoption of ICT by MSEs in the Nigeria and recommends that government should ensure efforts are geared towards the attainment of full ICT adoption by MSEs in Nigeria.

In a study, Ongori (2009) found that SMEs are sometimes, forced to deploy ICT because of competition as they are often forced to provide quality products at a cheaper rate. The study concluded that SMEs in some cases adopt ICT in their business process so as to easily access international markets, access robust information and seal inter and intra business transactions. Shettima \& Sharma (2019) also found that proper adoption of ICT in the business processes of SMEs have important roles to play both in terms of increased productivity and general boosting of economic activities. This will lead to making the mode of operating businesses less complicated along with other associated benefits. In a related research, Attom (2014) noted that ICT infrastructure and innovations are so insignificant in SMEs due to insufficient knowledge of ICT, lack of skills and high implementation costs. There is the tendency that these SMEs will be faced with severe growth and expansion challenges in the modern world of business where ICT is the other of the day. The cost of proper ICT integration in business processes cannot be overemphasized. Ion et al. (2008) described some of these costs as consisting of both direct and indirect costs. Direct costs of ICT adoption which might include but not limited to the costs of hardware, software, upgrades, training and consulting, maintenance as well as the costs of maintaining network security are most often underestimated while budgeting. Sometimes, this may include unexpected additional hardware, installation and configuration costs that will be associated to the equipment. Mwangangi et al., (2014) in describing ICT adoption by SMEs in Kenya, acknowledged the enormous benefits to be derived when SMEs adopt ICT solutions but noted that these implementations including the hardware, software and other associated costs that accompany such deployment are often too expensive to most SMEs considering their low turnover and slim profit margins. The researchers suggest that SMEs should consider open source software solutions along with scalable hardware platforms for progressive upgrades.

In the developed countries the rate of ICT utilization in SMEs business processes seems to have taken a different dimension depending on the country. The EU launched the ICT Innovation for Manufacturing SMEs (I4MS) initiative in 2013 (Europa, 2019), to connects SMEs, startups and mid-caps with European Digital Innovation Hubs, who help companies to test and adopt the latest digital technologies. The main aim of this initiative is to ensure the dominance of Europe in the manufacturing sector through the adoption of ICT, with special focus on SMEs. Nomsa $\&$ Tebogo (2017) while acknowledging the fact that SMEs makes huge contribution to the economy of a country, noted however that they are often characterized by low performance and high failure rates which is often blamed on lack of resources such as funds, land and skilled labor. Onu et al., (2015) in a similar research also observed a strong positive relationship effect between aggregate output, technology usage, work environment, and management style. 
The technological usage in production processes has the highest contribution to boost aggregate output performance of employees in sachet and table water manufacturing companies. Lu et al., (2019), however submitted that the differences in how organizations value information and other intangible assets that comes after the adoption of ICT by some of these SMEs is the reason why they tend to adopt cheaper ICT models, employing the use packaged software rather than customized ICT.

Okundaye et al., (2019) concluded that both government leaders and the executives of SMEs have critical roles to play in ensuring that SMEs have all the critical resources they needed to survive while the leaders of SMEs should ensure the successful adoption of ICT in their organizations.

\section{MATERIALS AND METHOD}

This research adopts the survey method of research design. In this research, the use of questionnaires was adopted. The questions are close-ended and include relevant factors that may be challenging proper ICT deployment in Nigeria such as (ICT skills, cost of ICT infrastructure, cost data, information security etc).

This research also made use of both primary and secondary data sources for the purpose of investigating these vital roles ICT can play in the viability of SMEs. The primary sources involve the use of questionnaires to gather relevant data from SMEs managers and decision makers, while the secondary data comprise of materials from textbooks, journals (published and unpublished), websites and news articles. The combination of these sources will enrich the study and give the researcher a better perspective into the study.

\section{DATA COLLECTION AND ANALYSIS}

In this study, 175 questionnaires were administered for comprehensive data gathering. The questionnaires were shared among five different industry categories comprising educational, micro finance, transport, commerce and hospitality sectors. Out of the 175 questionnaires administered, 150 of them were returned and fully completed. It was observed that many SME executives were scared of completing the questionnaire with the belief that it might be used for tax purposes and that accounts for the remaining 25 uncompleted ones.

Completed questionnaires were analyzed using Statistical Package for Social Sciences (SPSS) simple averages and chi-square technique to test the hypothesis. The justification behind using chi-square for the analysis of the data with $\mathrm{k}-1$ degrees of freedom, where $\mathrm{k}$ is the number of categories, is driven by the fact that the responses gathered fall into categorical data. 


\section{RESULTS}

\section{TEST OF HYPOTHESIS}

This research is conducted based on the following hypothesis

$\boldsymbol{H}_{\boldsymbol{o}}$ : We acknowledge that ICT plays a prominent role in the socio-economic development of Nigeria and companies who have adopted its use have remained viable and competitive

H1: $\quad$ ICT have little or no impact in the viability of businesses in Nigeria

In this research we are conducting two chi square tests for both productivity and barriers to ICT adoption by SMEs.

TABLE 1: ICT Investment Cost Justification

\section{ICT MAKES THINGS EASIER * ROLE OF ICT JUSTIFIES COST CROSSTABULATION}

\begin{tabular}{|c|c|c|c|c|c|c|}
\hline \multirow{3}{*}{$\begin{array}{l}\text { ICT } \\
\text { MAKES }\end{array}$} & \multirow{2}{*}{ NNo } & & \multicolumn{3}{|c|}{ COST (PROO5) } & Total \\
\hline & & \% within PRO004 & $\begin{array}{l}\text { No } \\
21.4 \%\end{array}$ & $\begin{array}{c}\text { Somehow } \\
50.0 \%\end{array}$ & $\begin{array}{l}\text { Yes } \\
28.6 \%\end{array}$ & $100.0 \%$ \\
\hline & & $\%$ within PRO005 & $4.8 \%$ & $16.7 \%$ & $8.7 \%$ & $9.3 \%$ \\
\hline THINGS & Someh & $\%$ within PRO004 & $30.3 \%$ & $23.7 \%$ & $46.1 \%$ & $100.0 \%$ \\
\hline EASIER & ow & $\%$ within PRO005 & $37.1 \%$ & $42.9 \%$ & $76.1 \%$ & $50.7 \%$ \\
\hline (PRO04) & YYes & $\begin{array}{l}\text { \% within PRO004 } \\
\% \text { within PRO005 }\end{array}$ & $\begin{array}{l}60.0 \% \\
58.1 \%\end{array}$ & $\begin{array}{l}28.3 \% \\
40.5 \%\end{array}$ & $\begin{array}{l}11.7 \% \\
15.2 \%\end{array}$ & $\begin{array}{r}100.0 \% \\
40.0 \%\end{array}$ \\
\hline Total & & $\%$ within PRO004 & $41.3 \%$ & $28.0 \%$ & $30.7 \%$ & $100.0 \%$ \\
\hline & & $\%$ within PRO005 & $100.0 \%$ & $100.0 \%$ & $100.0 \%$ & $100.0 \%$ \\
\hline
\end{tabular}

Table I presents a crosstabulation analysis comparing the respondents' opinion that ICT makes work easier viz-a-viz the cost of deployment and maintenance. It is clearly shown that though about $90 \%$ of the respondent are of the opinion that ICT have some level of influence on increased productivity, however the cost of deployment remains a major concern as about $41 \%$ believes that the cost does not justify the role played by the adoption of ICT. 
TABLE 2: Development and Maintenance Vs Data Communication

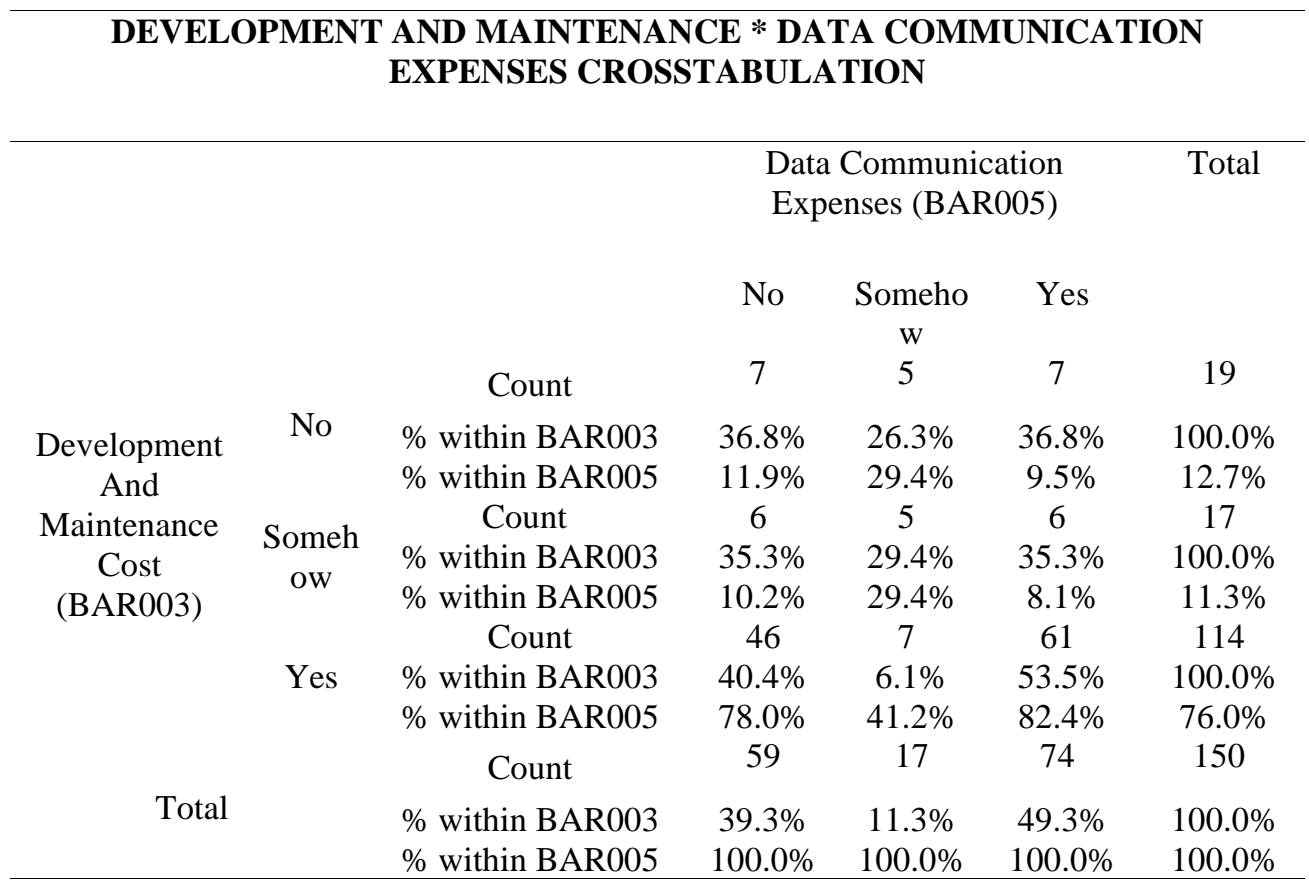

Apart from security threats and ability to optimize the use of technology that comes with adoption of ICT by SMEs, cost element is another factor that often discourages SMEs from incorporating ICT in their management processes. Table II above seeks to find a correlation between development and maintenance costs and data communication expenses. It is observed that about $80 \%$ of the respondents who are of the view that the cost associated with developing and maintaining ICT facilities is very high are also concerned about the high cost of data communication expenses. This is in line with the finding Lu et al., (2019) where these SME executives opts for cheaper alternatives. The charges from telecommunication companies arising from data communication and internet service providers between users are still on the high side in Nigeria and this remains a barrier as most SMEs are expected to compete with bigger and well-established companies including multinational corporations.

TABLE 3: Chi-Square Tests on Barriers Hindering Ict

\begin{tabular}{lccc}
\hline & $\begin{array}{c}\text { Value- } \\
\text { Obtaine } \\
\text { d }\end{array}$ & Df & Asymp. Sig. (2-sided) \\
\hline Pearson Chi-Square & $13.192^{\mathrm{a}}$ & 4 & .10 \\
Likelihood Ratio & 11.320 & 4 & .23 \\
N of Valid Cases & 150 & & \\
a. 2 cells $(22.2 \%)$ have expected count less than 5. The minimum expected count is 1.93.
\end{tabular}


As shown from the Pearson Chi-Square that $\mathrm{X}^{2}=13.192, p=.10$. This implies that there is statistically significant association between cost of maintenance and cost of data communication testing for $5 \%$ level of significance. The result obtained here shows that there is relationship between the two costs incurred by SMEs in the process of adopting ICT and this possess a common challenge to managers and entrepreneurs.

TABLE 4: Chi-Square Tests on Productivity

\begin{tabular}{lccc}
\hline & $\begin{array}{c}\text { Value- } \\
\text { Obtained }\end{array}$ & Df & Asymp. Sig. (2-sided) \\
\hline Pearson Chi-Square & $13.700 \mathrm{a}$ & 4 & 0.08 \\
Likelihood Ratio & 13.584 & 4 & 0.09 \\
N of Valid Cases & 150 & & \\
a. 2 cells $(22.2 \%)$ have expected count less than 5. The minimum expected count is 3.74.
\end{tabular}

From the Pearson Chi-Square that $\mathrm{X}^{2}=13.700, p=.08$. This result shows that there is statistically significant association between ICT adoption and increased productivity testing for 5\% level of significance.

Based on these two chi square results, the Null hypothesis $\mathrm{H}_{1}$ was rejected hence concluded that ICT adoption and proper deployment have a significant role in the profitability and sustenance of SMEs in Nigeria. Despite the challenges being faced by these entrepreneurs, it is obvious that their benefits cannot be overlooked in the development and advancement of any economy.

\section{DISCUSSION}

The result obtained from this research shows that there is relationship between the two variables of adoption and productivity. SMEs that have experienced full adoption of ICT in the decision-making process have often demonstrated increased efficiency and better customer satisfaction which leads to patronage and profitability. It was revealed that most SMEs shy away from the cost implication of adoption of ICT for optimal performance for various reasons. While the initial cost of deployment has been seen as the reason professed by these SME managers, it is noteworthy that this cost fades away within a reasonable period of time. Another common excuse gathered from the study is the fear of security breaches either as a result of virus attack, hackers or compromise on the part of aggrieved staff. (Kolodgy et al, 2002) posit that SMEs face various network security challenges as a result of interconnections, which expose them to different kinds of threats.

The results obtained from this research shows that there is relationship between the two variables of adoption and productivity. There is clear indication that SMEs that have experienced high level adoption of ICT in the decisionmaking process have often demonstrated increased efficiency and better customer satisfaction, higher level patronage and profitability. It was revealed that most SMEs shy away from the cost implication of adoption of ICT for optimal 
performance for various reasons ranging from high initial deployment costs, insecurity, loss of absolute control to other issues arising from technology adoption.

Findings of the research further revealed that (1) low awareness level of the inherent benefits of ICT incorporation in the management process of most SMEs has been a major cause of its low adoption; (2) poor media transmission framework, high cost of ICT hardware, deficient government support and legislation for internet business among other factors have hindered the adoption of ICT in the management process of SMEs; (3) high cost of funds in Nigeria have also made it unprofitable for SMEs to source fund for ICT expansion and implementation.

The study shows that measures that can promote investment on technology infrastructure, appropriate legislation and setting up implementation and monitoring mechanism to promote the utilization of ICT among SMEs and building an adequate investment climate to attract new investors will be appreciated by all concerned parties.

\section{CONCLUSION AND RECOMMENDATIONS}

The outcome of this study shows that Nigeria SMEs are been moderate in embracing ICT as they face significant requirements, for example, poor media transmission framework, constrained ICT education, powerlessness to incorporate ICT into business forms, high cost of ICT hardware, deficient government support and legislation for internet-based businesses, fragile ICT methodologies, absence of innovative work and shortcomings in deployments among others. Though huge investment and attempts have been made by both past and present administrations to assist SMEs both in terms of facilities and favorable legislations to ensure their viability, it is seen that most of these efforts fail at their implementation levels. Most banks and fund management organizations only support short- and medium-term loans even with high interest rates.

Accordingly, the following recommendations are proposed:

- Managers of SMEs should endeavor to explore numerous options available to them before making ICT infrastructural decisions.

- Users of ICT and indeed almost all staff in the organization must be aware of ICT adoption decisions and their various roles towards how to maximize its potentials

- Governments and stakeholders should provide adequate and friendly environment for SMEs

- Soft loans and targeted long-term facilities should be made available for duly registered SMEs to reduce the burden of outrageous interests charged by fund providers.

- Telecom regulators and service providers must be compelled to be responsive and live up to their expectations rather than placing unnecessary charges and bills even with dismal services.

- Power problems ranging from incessant outage resulting in high cost of energy generation to irregular voltage supplies must be checked. This most often destroys sensitive ICT equipment resulting in high replacement costs.

\section{CONFLICT OF INTEREST}

None 


\section{REFERENCES}

Akomea-Bonsu, C., \& Sampong, F. (2012). The impact of Information and Communication Technologies (ICT) on Small and Medium Scale Enterprises (SMEs) in the Kumasi Metropolis, Ghana, West Africa. European Journal of Business and Management, ISSN 2222-1905 (Paper) ISSN 2222-2839 (Online), Vol 4, No.20, 2012

Apulu, I. (2012). Developing a Framework for Successful Adoption and Effective Utilization of ICT by SMEs in Developing Countries: a Case Study of Nigeria. Unpublished PhD Thesis of the University of Wolverhampton.

Attom (2014), The impact of Information Communication Technology (ICT) on business Growth strategies of Small and Medium-scale Enterprises (SMEs) in the Awutu-Senya East Municipality of Central Region of Ghana, Asian Journal of Business and Management Sciences ISSN: 2047-2528 Vol. 3 No. 02 [13-28

Beal T (2002), Information and Communications Technology in Asia Pacific Countries: implications for small and Medium enterprises in Malaysia, Australasian Journal of Information Systems 10(1) DOI: 10.3127/ajis.v10i1.173

BusinessDay (2019), Top 100 Fastest Growing SMEs in Nigeria, https://businessday.ng/interview/article/top-100fastest-growing-smes-in-nigeria/ (Accessed $15^{\text {th }}$ October, 2020)

CBN (2003), Small and Medium Industries Equity Investments Scheme (SMIEIS), CBN Training Centre, Lagos, NO. 4 https://www.cbn.gov.ng/documents/smeeis.asp (Accessed 22 June, 2020)

Europa (2019), Shaping Europe's digital future Policy, ICT Innovation for Manufacturing SMEs https://ec.europa.eu/digital-single-market/en/innovation-ict-manufacturing-smes (Accessed $14^{\text {th }}$ October, 2020)

Hassan, H. \& Ogundipe A. (2017), ICT Adoption by Micro and Small-Scale Enterprises in Nigeria: A Case Study of the Federal Capital Territory, Abuja. Available at SSRN: https://ssrn.com/abstract=2951901 or http://dx.doi.org/10.2139/ ssrn.2951901

Houghton, K. \& Winklhofer, H. (2004), The Effect of Website and E-commerce Adoption on the Relationship between SMEs and Their Export Intermediaries, International Small Business Journal, Vol. 22, No. 4, pp. 369-388.

Ion, P. \& Z. Andreea (2008), Use of ICT In SMEs Management Within the Sector of Services, The Journal of the Faculty of Economics - Economic, University of Oradea, Faculty of Economics 4(1): 481-487.

Kolodgy, C. et al., (2002), Meeting the Growing Security Needs of Small and Medium-Sized Enterprises Extensible Appliances Fortify Resellers' SME Security Solutions. An IDC White Paper Sponsored by eSoft [Online]. Available from http://s3.amazonaws.com/zanran_storage/ www.esoft.com/ ContentPages/44263219.pdf (Accessed 25 July, 2020)

Lymer, A. (1997), The Internet and Small businesses: a study of impacts. Fifth European Conference on Information System, Colorado, 1997, pp. 145-162

Lu, H., Pishdad-Bozorgi, P., Wang, G., Xue, Y., \& Tan, D. (2019). ICT Implementation of Small- and Medium-Sized Construction Enterprises: Organizational Characteristics, Driving Forces, and Value Perceptions. Sustainability. https://doi.org/10.3390/su 11123441 
Mekwunye U. (2018), Nigeria: Small And Medium Scale Enterprises In Nigeria - An Overview Of Initial Set Up, https://www.mondaq.com/nigeria/directors-and-officers/757432/small-and-medium-scale-enterprises-innigeria-an-overview-of-initial-set-up (Accessed 15th April, 2020)

Minton, S. (2003), Nordic Nations still top information index, The World Paper. [Online] Available from http:// www.worldpaper.com/ 2003/oct02 /isi1.htm (Accessed 10 ${ }^{\text {th }}$ July, 2020)

Mwangangi, S., Ombuki, C. and Odote, G (2014), Role of Information and Communication Technology Solutions on The Growth of Small and Medium Enterprises: Case of Nairobi County, International Journal of Academic Research in Business and Social Sciences, Vol. 4(9) pp 275-290

Nomsa, S. and Tebogo, I. (2017), Strategic Planning in Small and Medium Enterprises (SMEs): A Case Study of Botswana SMEs, Journal of Management and Strategy, Vol. 8, No. 1; 2017

OECD (2000), Small and Medium-sized Enterprises: Local Strength, Global Reach, The Organization for Economic Co-operation and Development [Online]. Available from www.oecd.org/publications/pol_brief (Accessed $10^{\text {th }}$ May, 2020)

Ogbo A. and Nwachukwu C. (2012), The Role of Entrepreneurship in Economic Development: The Nigerian Perspective, European Journal of Business and Management, ISSN 2222-1905 (Paper) ISSN 2222-2839 (Online), Vol 4, No.8, 2012

Okundaye K., Fan Susan \& Dwyer R. (2019), Impact of information and communication technology in Nigerian small-to medium-sized enterprises, Journal of Economics, Finance and Administrative Science, ISSN: 22180648, Volume 24 Issue 47

Oni O., Daniya A. (2012), Development of Small and Medium Scale Enterprises: The role of Government and other Financial Institutions, Arabian Journal of Business and Management Review (OMAN Chapter) Vol. 1, No.7; February 2012

Ongori H (2009). Role of Information Communication Technologies Adoption in SMES: Evidence from Botswana. Research Journal of Information Technology, 1: 79-85. DOI:10.3923 /rjit.2009.79.85, URL: https://scialert.net/abstract/?doi =rjit.2009.79.85

Onu, C., Olabode I. \& Fakunmoju S. (2015), Effect of Information Technology Investment on Organizational Productivity and Growth of Small and Medium Scale Enterprises in Developing Countries”, Business and Economics Journal, Bus Eco J 6: 152. doi:10.4172/2152-6219.1000152

Mohammed. B. S. \& Naveen S. (2019), Impact of Digitalization on Small and Medium Enterprises in Nigeria. Adalya Journal. Volume 8, Issue 12, December 2019. Pp 635-644. ISSN NO: 1301-2746. http://adalyajournal.com /gallery/60-dec-2465.pdf

Rees L. (2019), SMEs key to driving sustainable growth and development in Africa, Johannesburg Business School, https://www.bizcommunity.com/Article/196/841/196072.html (Accessed 10th January 2020)

Sajuyigbe, A. \& Alabi E, (2012), Impact of information and communication technology in selected small and medium enterprises in Osogbo metropolis, Nigeria. Journal of school of communication and information technology, Federal Polytechnic, Offa. Vol. 3 No.1

Taiwo.N., Falohun, T. \& Agwu, E. (2016) SMEs financing and its effects on Nigerian economic growth. European Journal of Business, Economics and Accountancy Vol. 4, No. 4, 2016 ISSN 2056-6018 